\title{
Anti-Capitalist Resistance in the Liberalist Context
}

\author{
Daniel Fletcher
}

Costas Douzinas challenges Slavoj Žižek's negativity towards the 2011 cycle of revolts in his Philosophy and Resistance in the Crisis (2013). Seeking to explore the central dynamics of the resistance movements that emerged in the wake of the global financial crisis, and especially those that emerged in the wake of the austerity measures associated with the European sovereign debt crisis, Douzinas focuses on the practices of direct democracy that emerged in the squares, which were occupied by the people who had lost patience with the political and economic establishment. Forms of direct democracy helped to re-empower peoples alienated from the governments that claimed to represent their interests, opening up a new constituent process that revitalized politics in the Muslim world, Southern Europe, and the United States. For Douzinas the direct democracy of the squares has helped to forge an emergent "social ethos" that opposes both the atomizing tendencies of liberal individualism and the totalizing tendencies of communitarian narratives. The social ethos locates human emancipation between these two extremes, in an individual who is autonomous but who recognizes that they share their existence with a community, so that "being in common is an integral part of being self" $(2013,195)$. The human subject often talks within a communal We, yet the subject is never subsumed by the We of a communion, and so retains the distinction of $\mathbf{I}$. Unlike Žižek, Douzinas embraces the emphasis on individual autonomy and open-ended association in contemporary demonstrations, resisting the temptation to fall back on old-fashioned socialist notions of disciplined centralization that supposedly help constitute commonality but which tend to crush freedom beneath the will of a vanguard.

As alluded to, while Douzinas is keen to embrace individual freedom within a collective project, he explicitly distances the social ethos from liberal individualism (see ibid. 90-96). For him the neoliberal system that penetrates ever deeper into the social fabric of a globalized society exacerbates the atomizing tendencies of liberal individualism by ramping up the culture of individual self-sufficiency. The austerity programs instituted by governments in the times of economic crisis are driven forward by the neoliberal ideology of self-sufficiency: governments demand that the people stop relying on state hand-outs and start taking responsibility for their own lives, with individuals implored to stand on their own two feet with discipline, self-control, and the appropriate level of self-interest. Despite, then, his emphasis on the importance of I, Douzinas follows in a long Marxist-leftist tradition that attempts to create a fundamental opposition between the liberal capitalist order -which in its radicalism can spread only an isolating culture of self-reliance and self-contained "freedom" - and radical movements for democracy, imagining the emergence of an egalitarian social culture to challenge anti-social liberal capitalism.

In this article, however, I will suggest that the concept of individuality through commonality -which Douzinas associates with what is postulated as an essentially non-liberal social ethos- has deep roots in liberal tradition and culture. The article will emphasize that liberalism is not synonymous with capitalism, even if it is compatible with it and often supports its development. It will be argued that the contemporary form of neoliberal capitalism does not represent the fulfilment of liberal ideology per se, but the fulfilment of one (arguably perverse) strand of liberal culture that prioritizes the struggle for individual power over the struggle for individual freedom. The article will argue that from its beginnings liberalism has always been in contradiction with itself, simultaneously perpetuating, on the one hand, possessive/power-seeking individualism, and, on the other, associational/egalitarian individualism. While the culture of possessive individualism has nurtured competitive capitalism, the culture of egalitarian individualism 
has cultivated a radical tradition of leftist-libertarian or anarchistic democratic struggle that in the contemporary age climaxes into the aganaktismenoi, the indignado, and Occupy movements. With this insistence on the radical liberalist character of contemporary protest movements, in this article I will suggest that it is not only inaccurate but also unhelpful to distance the histories of liberalism and democracy in the way that Douzinas does. By facing up to and inhabiting the liberalist character of contemporary resistance movements, we are in a better position to draw out and develop progressive associational/egalitarian individualist notions, such as free association, shared desires, joint self-constitution, egalitarian cooperation and mutual support, whilst remaining conscious of the inherent dangers of movements sliding towards possessive individualism and power seeking. In short, we will be in a better position to discuss how we can keep the spirit of democratic radicalism within its own spirit.

The perspective developed in this article draws much inspiration from DeKoven's (2004) analysis of the birth of the postmodern through the radical struggles of the 1960s. DeKoven notes that the postmodern capitalist system that emerged from the 60 s seemed to carry its own forms of resistance within itself, producing and absorbing radical struggle to simultaneously strengthen and undermine itself. What I will try to do in this article is demonstrate that the capitalist system has always carried within itself not just the material conditions but also the culture of its own destruction, for it is dependent on a liberalist ethos that branches off into a supportive possessive culture and a subversive egalitarian culture. Ingrid Hoofd's arguments (2012) on neoliberal contradiction are also relevant here. Hoofd notes that the contemporary era's fast capitalism is premised on the speed elitism of the system, which compels corporations to continuously draw on new technology in order to continuously speed up the integration of global markets and the accumulation of capital. Hoofd, however, in analyzing the contemporary alter-globalization movement's opposition to neoliberal capitalism, notes that the movement carries within itself speed elitist tendencies, encouraging the breaking down of all barriers to movement and communication as well as the increasing mobilization of western knowledge and technology to overcome the apocalyptic threat of climate change. Hoofd considers zealous and/or unreflective embraces of such processes of integration and mobilization by alter-globalist activists to be speed elitist because they inadvertently help speed up Western-led globalization and the hegemony of western culture and western markets that is carried forward by such globalization.

From a post-structuralist perspective, Hoofd suggests that the alter-globalization movement "cannot help" (ibid. 19) but carry forward the tendencies of the system it is opposing because its existence is bound up in Western culture and ideology. Specifically, Hoofd argues that like neoliberalism, alter-globalism is caught in a "humanist aporia" (ibid. 22), with the latter affirming the very struggle of the active/activist subject-agent that neo-liberal expansion is dependent upon - Hoofd suggests that the term activist is itself a highly value-laden term rooted in economistic notions of active endeavor to enrich and push forward the advance of the capitalist nation-state. The neoliberal system encourages, even compels its subjects to be active, creative and free. In doing so, it attempts to channel autonomous action towards capital accumulation, but in encouraging creativity and autonomy, it inadvertently encourages resistance against itself, sparking new forms of association and the development of forms of freedom and justice that it cannot control. The alter-globalization movement is the product of this process, but while it seeks to overturn the domineering and exploitative nature of the system, it remains a product of the system, and therefore remains caught up in and fed by the system's processes and dynamism. Building on Hoofd's argument, in this article I intend to place the humanist contradiction of neoliberalism in its historical context, arguing that the contradiction has been growing ever since liberal culture and ideology emerged in embryonic form in the 17th century. The neoliberal cultural context, then, is constituted by two oppositional but interdependent dynamics of exploitation and resistance that have been accelerating towards their present states since the early stirrings of liberal capitalist society, and as the two dynamics continually burgeon and intensify, they exacerbate the possession versus association contradiction of neoliberal society and threaten to pull it apart.

The radical protestors of the neoliberal age are heirs to a long history of self-emancipatory radicalism that has emerged in tandem with the bourgeois history of self-advancement. Liberalist culture has sustained bourgeois power, but the self-emancipatory tendencies of that culture lead into anti-authoritarian sentiments and the search for the formation of the self in common with others. It is here that we find, tightly rooted in the liberalist context, a social ethos, an ethos which contains genuinely anti-capitalist tendencies but which emerges out of a bourgeois striving to find or save the self. In order to demonstrate the contradictory character of liberalist culture, this article will compare the contradiction of self-emancipation in the philosophy of two men who are posited as among the earliest liberalist thinkers; Baruch Spinoza and John Locke. I have chosen these two authors in order to help me re-conceptualize the history of democratic radicalism that is posited by two of the most famous writers on contemporary anti-capitalism; Michael Hardt and Antonio Negri. Hardt and Negri conceptualize a Western history of absolute division between 
the egalitarian, constituting multitude and the hierarchizing, constituted power of capitalism, postulating a vision similar to Douzinas's on the irreconcilable opposition between the neoliberal forces of power and the people's forces of liberation. In their seminal work, Empire, Hardt and Negri outline their history of radical democratic struggle, rooting it in the Renaissance humanism that blossomed in Medieval Italy, while setting up Spinoza as the philosopher who encapsulated the radical democratic spirit in the 17th century. While Hardt and Negri make no links between Spinoza and the liberal tradition and imply an essential distinction between Spinoza's philosophy of commonality and liberalism's philosophy of individualism, in this article I will highlight the ways in which Spinoza's philosophy gave expression to an emergent liberalist ethos, an ethos which was developed further in the philosophy of Locke. Critically, I will demonstrate that it is not reasonable to simply extract an anti-social core from the liberal tradition, for even in liberalism's early embryonic stage democratic radicalism was as essential to liberalist thought as was possessive radicalism.

The Dutch Jew Spinoza was resident in the burgeoning Dutch Republic of the 17th century, writing at a time when the merchants of the United Provinces were beginning to establish themselves as a patrician merchant oligarchy. As noted above, Hardt and Negri closely associate Spinoza with the rise of Renaissance humanism and democratic radicalism, but they greatly underplay the extent to which Spinoza's metaphysics gives expression to the unbounded optimism of the merchants of the Dutch Republic, whose spirit defined the Republic's culture and drove forward a nation in the throes of global trade domination. Spinoza was himself from a merchant family - although not a particularly wealthy one - and helped to run the family importing business after his father's death. Spinoza's venture into business was not successful and he ended up becoming an artisan of sorts, working as a modest lensgrinder and instrument maker. Feuer (1958) argues that Spinoza gave up his business interests because of his reaction against the competitive capitalism that marked the outlook of the Jewish elite and the influential, conservative Calvinists (6). Nevertheless, Spinoza remained very much part of the dominant merchant-artisan Bürgertum estate, and he would emerge in the 1660 s as a liberal republican supporting the republican Dutch government led by the Grand Pensionary of the Netherlands, Johan de Witt, a man who represented the trade-orientated interests of the oligarchic patrician merchant class (see Žižek, 2004, Deleuze, section 6). For Feuer, while it is true that Spinoza became a moderate republican, this was only after he had started to move away from the religious and political radicalism he had initially embraced in reaction against Holland's conservative elite (from the mid-1650s, around the time of his excommunication from the Jewish community in Amsterdam, Spinoza became closely associated with Utopian radicals in the city, some of whom, like Franciscus Van den Enden, held revolutionary egalitarian ideas (Nyden-Bullock, 1997)). Nevertheless, it should be remembered that the religious radicals - who, Feuer suggests, in a similar vein to Hardt and Negri, broke apart the order of the medieval world - still tended to emerge from the Bürgertum estate, and really only radicalized - and in radicalizing, developed - the self-emancipatory ethos of the elite merchants. Because of the diffuse self-emancipatory ethos uniting radical and moderate members of the Bürgertum, one can understand how a radical such as Spinoza could so easily become a moderate, and why deeply radical notions of existence would remain central to his philosophy even as his political outlook mellowed. Spinoza's self-emancipatory ethos will be explored below.

More so than his actual political philosophy, Spinoza's naturalistic metaphysics inspired the democratic radicalism of the French Enlightenment, significantly influencing the political thought of the encyclopèdistes who laid the ideational groundwork for the French Revolution of 1789 (Israel, 2011). Deleuze and Guattari (1984, 1988) inherited this French radical legacy, drawing on it (as well as on Spinoza explicitly) to develop their materialist metaphysics of interconnected desiring multitudes, which would be developed into a clear political vision by Hardt and Negri in Empire (on Deleuze and Guattari's influence on Hardt and Negri, see Hardt and Negri, 2001, 23-28 and 415). Spinoza's metaphysical radicalism, elaborated on most fully in his magnum opus, Ethics, lay in his willingness to ground human behavior in a non-teleological nature. For Spinoza, God is immanent in this nature, and cannot be thought of as a transcendent being who bestows special status on certain human beings. Spinoza, then, humbles mankind by suggesting that no man, not even a king, can raise himself up by drawing on the transcendent "power of god" (see TTP 6, 81 - see Spinoza, 2007). Here Spinoza, like Locke, undermines the divine right of kings, but because of his metaphysical naturalism Spinoza's conclusions on rights are starker than Locke's - for Spinoza, without a transcendent legislator, an individual has no natural entitlements, or natural rights in the Lockean sense, at all.

With no conscious Will, God has no normative order to offer, and there is therefore no natural law that mankind is compelled to follow. Spinoza, then, would not be able to abide by Locke's assertion that even in the state of nature men are obliged to follow the natural law of God's reason - Spinoza explicitly rejects the idea of "men in nature 
as a state within a state" (TP 2/6 - see Spinoza, 2000). For Spinoza, ultimately men have "sovereign natural right" only to the extent that any other creature has it. That is to say, a man has the "right" to do anything that his natural faculties enable him to do, just as, for example, natural faculties give fish the right to "have possession of the water" (TTP 16, 195). Significantly, Spinoza is asserting here that natural right is synonymous with natural power. A man's powers, or natural faculties, drive him to persevere in his being (E IVP18S - for the Ethics, see Spinoza, 1985). This is a radical conception of an individual's power because it leads Spinoza to the conclusion that men are never bound to adhere to the covenants set in place by a sovereign authority. If a group of individuals decide that a covenant is detrimental to their striving to persevere in being, and if they have the collective power to oppose the sovereign, then they have the natural "right" to ignore the covenant or to declare it "null and void" (see TTP 16, 182). Ultimately, no man can transfer his natural right to the sovereign and be forced to follow the sovereign's whims, for his natural right is his natural power, or his inherent ability to act on his strongest interest. A man, therefore, will inevitably defy the sovereign if it is in his interest to do so. And here emerges the potentially revolutionary implications of Spinoza's philosophy. For Spinoza, unlike for Locke, the people do not have an inalienable juridical right to overthrow an unjust government; nevertheless, for Spinoza the government retains the "right" to its power only to the extent that it appeases the people. If a sovereign does not rule in the people's interests, the people will inevitably challenge its power with their collective counter-power. Regardless of any formal social contract, then, Spinoza believed that any government that wanted to survive in the long-term would be compelled to accept constitutional limitations to ensure that its power was not at odds with the interests and natural power of the people (Sharp, 2013).

For Hardt and Negri, despite Spinoza's acceptance that a constituted sovereign power can survive if it compromises with the people - an acceptance which marks Spinoza as politically moderate or "liberal" - Spinoza's underlying ontology remains radical because Spinoza continues to assert that a sovereign can never really take away the people's collective power; a sovereign's assertions of right remain superficial, dependent on the unlimited constituent power of the people, or the people's potentia. A state grasps only a temporary constituted power or potestas, an institutionalizing force that limits the multitude's possibilities and overdetermines its potential (see Field, 2012, 23). In his Political Treatise, Spinoza explains that the state emerges spontaneously out of the natural passions of men. Recognizing that they are individually weak and vulnerable to the sway of the passions, men feel compelled to forge civil society and constitute a sovereign state, being drawn together by "some common emotion... common hope, or common fear, or desire to avenge some common injury" (TP 6/1). Although the state is designed to control the anti-social potential of the passions, it remains forged through the passions, and this for Hardt and Negri offers the hope of the emergence of organic, pre-institutional and non-hierarchical forms of social organization that remain constituent without collapsing into a solid, overarching constituted order.

Nevertheless, in extracting a radical democratic tendency from Spinoza's philosophy, Hardt and Negri overlook a key piece of Bürgertum or proto-bourgeois conservatism that is essential to Spinoza's view of humanity. As Sandra Field points out in her excellent critique of Negri's interpretation of Spinoza (2012), it seems pretty clear that Spinoza does not share Hardt and Negri's optimism about a free desiring multitude. Civil society may emerge out of the passions, but for Spinoza, without the state to control the passions, collective desire cannot be maintained, and civil society collapses into the war of each against all. Spinoza is indebted to Hobbe's view of human nature, suggesting that human beings are generally not rational and tend to be overwhelmed by sad and vicious passions (see EIVP54S), being "more inclined to vengeance than compassion" (TP 1/5). Spinoza, unlike Hobbes, does not suggest that individuals must give absolute power to the sovereign in order to protect humanity from the war of each against all. Nevertheless, Spinoza does not suggest, as Negri claims he does, that free individuals in unmediated social relations will tend towards a collective of horizontal unity and harmony. Because destructive passions tend to overwhelm human reason, individuals rely on the state to protect themselves from themselves. Spinoza, then, seems to directly challenge Hardt and Negri's ontology of emancipatory desire by suggesting that the multitude cannot preserve and nourish its being by following its passions. Indeed, it is precisely passions that hold back the collective potential of the people, which is why Spinoza focuses on the need for strong institutions to channel passions towards the common good. As Field succinctly notes, for Spinoza, "the power of the multitude is inseparable from the institutional mediation that shapes it" $(2012,22)$.

In the Ethics, Spinoza famously rejected Descartes's mind-body dualism and insisted that, while mind and body may be two finite modes of different attributes, they are of one ontological substance, a substance that is the infinity of nature and God. Hart and Negri celebrate this as a thoroughly materialist conception of the Real that opens up the possibility of human beings who come to live in harmony with their own bodies and all the other bodies of nature; the conception leads to the realization of the essential interconnected unity of all things. However, it should 
be remembered that Spinoza's monism remains premised on the notion of the rational mind overcoming the body's irrational passions. For Spinoza the passions are external and passive forces affecting the mind. The human mind strives alongside the human body to persevere in being, but desires rooted in the body impress upon the mind a striving after inadequate ideas (EVP20S). However, through its striving to persevere in its being, the mind creates its own adequate ideas that are felt as active affects (see Dutton, 2014). These are active joys and desires that guide man towards a rational understanding of the world. It is this rational understanding that frees mankind from the sway of the passions, leading us to harmony with the world, a world whose affective powers would otherwise overwhelm us.

What we can see here is that, again, Spinoza's ontology cannot support Hardt and Negri's embrace of corporeal desires. Spinoza develops the rather conservative rationalist denigration of passions of the body, which are always inadequate, while elevating the rationalizing mind, which alone can lead the human to adequate ideas and the highest good - knowledge of God. For Spinoza, the mind emerges out of the one ontological essence to lead the human towards the true preservation of its being. The mind cannot detach itself from the body - indeed, it shares its being with the body - but it alone reorients the human being towards spiritual perfection with its divine self-constituting and self-perpetuating power. Ultimately, then, Spinoza's notion of human freedom is egoistic and idea-led, amounting to an early version of Žižek's psychoanalytic philosophy of the transcendental mind that frees human being by emerging from the limited body to reconnect the human entity with the limitless potential of the primordial soup of quantum waves (see Žižek, 2004, on Spinoza’s place within modern philosophy[1]). As such, Spinoza's philosophy, rather than a precursor to the anarchistic culture of contemporary anti-capitalism, is a precursor more to the centralizing socialist tradition, which elevates an ordering mind over mass or popular self-organization and spontaneity. While Hardt and Negri present Spinoza as the philosopher who outlined the ontological power of an autonomous multitude, thereby laying the foundations for a postmodern notion of sovereignty, Spinoza's philosophy actually seems to fit much more comfortably with what Hardt and Negri describe as a modern notion of sovereignty, which is premised on a command mentality (see 2001, 69-85).

Although Jewish, Spinoza was shaped by the United Provinces' Christian radicalism, being caught up in Northern Europe's Protestant Reformation. Deleuze and Guattarisuggest that Protestantism played a critical role in individualizing belief (see Dosse, 2010, 203), but in doing so it built on the proto-individualist radicalism of merchant-led Renaissance humanism. The merchants' culture of self-mastery encouraged the rejection of the Catholic Church's transcendental overlordship, spurring Protestantism's embrace of the individual who takes control of the search for freedom and salvation. Even as Protestantism collapsed towards its institutionalized, magisterial forms, it continued to be animated by an undercurrent of groups embracing self-emancipatory radicalism. While the elite Dutch merchants, overseeing the institutional conservatism of the Dutch Reformed Church, could not let go of their oligarchic power, the marginalized religious radicals of the Bürgertum - Spinoza among them - challenged the elite to bring out its own ethos by opening up the social and productive process. The radicals embraced the emergent self-emancipatory ethos by refusing to relent in their search for individual freedom. The radicals may have struggled for a new collective unity, but their struggle emerged out of the merchant struggle for the self and remained premised on the search for self-betterment. Let us again remember here that Spinoza, as one of these radicals, championed civil society only to the extent that it was "consonant with individual liberty" (TTP 16, 207), founding his argument on the essential, self-centered drive to persevere in being:

Since reason demands nothing contrary to Nature, it demands that everyone love himself, seek his own advantage, what is really useful to him, want what will really lead a man to greater perfection, and absolutely, that everyone should strive to preserve his own being as far as he can (EIVP18S).

As Spinoza searched for what was really in the self-interest of man, he came to the conclusion that an individual's salvation could only be achieved in harmony with others. As a result, Spinoza helped to open up the contradiction of the liberalist ethos, bringing out associational desires with his pantheistic metaphysics, complicating the selfish merchant push for self-mastery and power. Many radical protestant groups of the era contributed to the emerging contradiction. Feuer notes, for example, that groups such as the Quakers and the Diggers in England, who shared in the same zeitgeist as Spinoza, also began to embrace pantheistic notions of human existence, believing that God's pervasive spirit united all of nature $(1958,53)$. As we shall come back to below, here the English radicals were driven by a desire to defend their property rights, but they understood property in a broad sense, defending the individual's right to be, and to be free through egalitarian association.

Ultimately, then, it seems reasonable to argue that while Spinoza's notion of people power was radical for its time, it was not clearly separate from the era's emergent liberalist ethos. Indeed, there seem to be some strikingly 
Lockean tones to Spinoza's concept of the multitude's potentia. Locke and Spinoza were both shaped by the 17 th century struggles against state absolutism and by the protestant radicalism that marked those struggles, [2] and Spinoza and Locke's zeitgeist is expressed by both authors with similar notions of individual liberty. Despite their very different metaphysical outlooks, both philosophers oppose state absolutism by emphasizing the power inherent in each individual. For both philosophers, all human beings are fallible because of their tendency to be swayed by the passions, but all are naturally imbued with God's reason, and for both philosophers this reason is the source of the human being's power. Through their reason humans can recognize the self-destructive tendencies of their desires and can form governments that will oversee social relations to ensure that all can flourish in their liberty. For both the potestas, or juridical power that the people consent to, is always dependent on the people's pontentia, the people's capacity for self-determination, a capacity which gives them the "right" to change or overthrow government that does not fit with their determination of individual liberty as expressed through the common good.

When Negri traces the radical democratic tradition back to the genesis of capitalism, he hopes to find a tradition clearly demarcated from capitalism's liberal individualism, and indeed, picking up on 17th century metaphysical radicalism, he imagines he has found the beginnings of this demarcated radical tradition in the work of Spinoza. But on closer inspection it seems that what he has actually stumbled across is a philosopher, who, along with Locke, gave expression to the era's emerging liberalist spirit, which, in reacting against the semi-aristocratic absolutism epitomized by Hobbes's philosophy, championed the power of the liberated individual while simultaneously asserting that individual power is most effectively expressed through associational action. As Field notes (2012, 23), Negri suggests that Spinoza's revolutionary democratic break is found within his insistence that "political power always remains concretely in the bodies of the human individuals who make up the multitude." This sentiment animates the great anti-totalitarian assertion that individuals always have the will and capacity, and therefore the "right," to break free from power structures that attempt to crush the individual beneath a transcendent force. Inconveniently for Negri, this assertion is as much Lockean and liberal as it is Spinozist and radical.

Interestingly, Deleuze and Guattari, Hardt and Negri's philosophical precursors, insist that one should attempt to find the radical ethos or essence in a philosopher, without getting too caught up in the historically rooted conservatism or prejudices that a philosopher might betray (see Hardt, 2006). This logic is used to justify overlooking Spinoza's sexism and his exclusion of servants, foreigners and those who do not lead "respectable lives" when he forms his vision of democracy (see TP 11/3). What it does not seem fair to do, however, is to extract radicalism from Spinoza, a favored author, while overlooking the potential radicalism in other authors, like Locke, who are more difficult to co-opt as radical figures because of their more obvious complicities in the development of the "enemy" system - the capitalist system (see Macpherson, 1962, on Locke's philosophy of accumulation. See also Armitage, 2004, on Locke's complicity in Afro-American slavery). Hardt and Negri may counter by arguing that Spinoza's core ethos was more radical than Locke's because of the way in which it embraces the notion of immanent commonality. Whereas Spinoza was an early Bible critic, Locke's justifications for his political views in the Two Treatises are replete with quotes from the Bible; indeed, Locke embraced the divine revelation of Scripture in The Reasonableness of Christianity (1958 [1695]). Locke's God, unlike Spinoza's, can be a transcendent God who reveals the natural law that mankind must follow even in the state of nature. With a notion of transcendence, Locke can champion inalienable juridical rights that overdetermine the people's inherent power. Nevertheless, as suggested above, Spinoza's rejection of transcendence is as much pragmatic as it is revolutionary, emerging out of a merchant culture of grounded selfreliance. Furthermore, as noted, for Locke juridical power is rooted in an immanent spirituality; it may descend from up high but it is a natural endowment within mankind that is their property - it is part of their natural capacity. One can extract an essentially radical ethos from Locke, then, because his essentially materialist notion of right undermines the transcendent power that he invokes to justify it. [3] Indeed, Locke's empirical epistemological vision arguably pushes materialist conceptions of existence further than Spinoza's semi-mystical rationalism, with the latter seeming to rely on the notion of a divine reason within the order of nature that is beyond the reach of sensory experience. Even in his materialist radicalism, then, Spinoza comes close to inserting a transcendental force into the natural order.

While in his lifetime Spinoza remained a marginalized figure lurking on the fringes of the bourgeois establishment, Locke's close relationship with an emergent bourgeois Whig oligarchy in England marks him out as a more mainstream philosopher. But we should not be deterred from seeking out radicalism that lurks within the conservatism of the mainstream, and Locke's philosophy is interesting precisely because it marks the rise of self-emancipatory radicalism to that mainstream. Of course as a radically subversive philosophical tendency moves into the mainstream it becomes moderated, even if something of its radical core remains. We should not, therefore, 
be surprised to find in Locke a much more conventional notion of God, nor a more explicit embrace of personal possession. In any case, it seems that Locke really only teases out or exposes the contradiction that constitutes the radical liberalist ethos embedded in Spinoza. While keen to embrace a divine equality, Spinoza insists on the preeminence of the striving individual, implicitly opening up the power-seeking tendencies of self-interested beings (for Žižek, Spinoza's assertion of a purely positive being of self-preservation leads him to embrace (and expose) the raw, competitive, "might-makes-right" tendencies that underlie the juridical equality propounded by liberal bourgeois ideology; see 2004, "Deleuze," section 6). Locke, for better or worse, gives expression to this liberalist contradiction in a more pragmatic way. Like Spinoza, Locke locates human being in the individual's striving for self-preservation, although he does not as clearly (or as idealistically) demarcate a divine mind from corporeal experience. As a result, he more explicitly embraces an individual's desire to claim ownership and better his or her self materially. Nevertheless, Locke's worldview remains premised on a relatively radical notion of a common spirituality that makes possible collective action through reason; for even though a man is born as an independent self, the reason or spirituality he shares with all others makes him always connected to mankind.

Locke's philosophy, then, is representative of the progression of the liberalist ethos from the margins to the mainstream, but as the ethos developed in the mainstream it was not simply corrupted or moderated - it was simultaneously radicalized in a possessive way and a democratic way. As noted, Spinoza largely embraces Hobbes' cynical concept of human nature, believing humans to be under the sway of their largely anti-social passions most of the time (see TTP 16, 200). Although he radically asserts that all men are born with the basic natural faculties needed to cultivate the reason that is necessary to control the passions (see TP 7/4 and 7/27), ultimately Spinoza believes that most men, most of the time, do not think or behave in the way that they should for their own good - that is, they tend not to behave rationally (see Den Uyl, 1983). Feuer (1958) identifies here a fundamental conflict in Spinoza's philosophy; Spinoza attempted to embrace a basic democratizing liberalism but ultimately did not trust in the ability of people to organize their freedom. For Spinoza, because of the overwhelming power of people's basic destructive nature, democracy - even Spinoza's limited form of democracy that borders on timocracy - seems to be postulated more as an ideal than a sustainable form of government (see Niemi, 2013, Section 5).

What we find in Locke, however, is a more optimistic concept of human nature. Locke introduces a basic civility into the state of nature, more fundamentally rejecting the Hobbesian war of each against all. As noted, Spinoza assumes that the notion of natural law, which Locke relies on to support his notion of the state of nature, is an artificial concept that idealistically posits a state within a state. However, as suggested, natural law is really used by Locke to aggrandize a vision of a basic human condition or state marked by civility. It is true that Locke, like Spinoza, follows the potentially elitist early Enlightenment idea that civility or morality is ultimately derived from reason. Nevertheless, civility for Locke seems much more firmly rooted in the basic physical nature of the human being civility emerging from a basic intuitive agreeableness. For the empiricist Locke the mind does not so much strive to overcome the bodily passions as it does record the patterns of sensual experience. Man's "obligation to mutual love" (Two Treatises, Essay 2, point 4), then, is the self-evident realization that man comes to simply by experiencing what life is - man, it seems, is essentially compelled to share in the sensual spirit that each man has by nature an equal stake in. While Locke shares in Spinoza's early liberal conservatism by promoting anti-popular mixed constitutions and by reducing humankind to mankind, Locke's fledgling democratic ethos seems to display more faith in people than Spinoza's.

Perhaps because Spinoza is more fearful of the liberated masses than Locke, he seems drawn to strong institutions of government that may tend towards absolutism. It can be argued that, in reacting against the selfish tendencies of individuals, Spinoza champions the idea of individuals binding themselves so closely together that they become a super-individual that acts with a single mind (see Den Uyl, 1983, and Barbone, 2001, for discussion of this idea). Indeed, especially in his Political Treatise when discussing aristocracies, Spinoza puts great emphasis on bodies of legal oversight that may represent super-individuals. For the liberal philosopher Isaiah Berlin, by reifying a superindividual state that subsumes individuals within itself, Spinoza dissolves individual freedom within the right of the overarching juridical body (1969). Furthermore, Spinoza develops a notion of universal or civil state religion that has a distinctly Rousseauian ring to it (see T'TP 14, 182-183). This is significant because Hardt and Negri are highly critical of Rousseau's philosophy because of its emphasis on a general will that subsumes the singularities of the multitude in the name of the common good $(2001,85)$. For Hardt and Negri, Rousseau's notion of the general will is tied up in bourgeois notions of transcendent power, a power that overrides democratizing flows. If we can interpret Spinoza's state as a juridical super-individual, then he may well express sentiments in line with Rousseau's general will. In any case, Spinoza and Rousseau's similar views on civil religion are perhaps most telling. Both philosophers 
seem to conceive of a sovereign that tolerates spiritual diversity but ultimately monopolizes spiritual virtue and forces all to bend to its rationalizations of right (see Feuer, 1958, on Spinoza's lack of defense for freedom of religious expression).

Locke and Spinoza are both products of their respective cultural and historical contexts, and the philosophies of both authors are important markers on the road of the progression of the liberalist ethos. Both authors are very much after Hobbes, who was really a conservative reactionary writing just before the final blow to absolute monarchy in England; he recognized the significance of the emergence of bourgeois individualism but was desperate to contain it within aristocratic totality (see Robin, 2011). Spinoza gives expression to the limits of early modern merchant-bourgeois (or Bürgertum) society, limits which were reached in the Dutch Republic in the 17th century. The Republic's undercurrent of Bürgertum radicalism, represented by Spinoza, which fed into an emergent liberal individualism with its accompanying free trade agenda (see De la Court brothers, close associates of Johan De Witt, for anti-guild, anti-oligarchy sentiments in the Netherlands in the 17th century; see Petry 1984), was not strong enough to counteract resilient oligarchic, feudal tendencies that continued to permeate through Dutch Bürgertum life. Spinoza's philosophy is revealing here, for as we have seen, even within Spinozist materialist radicalism there lurks a deep fear of the unfettered masses and a strong proto-transcendental rationalist presence that seems strongly influenced by an aristocratic command mentality. In England after the Glorious Revolution of 1688, however, the patrician-merchant ideology of feudal totality began to break apart. Locke's thought is a product of this context, being representative of the early stirrings of a post-medieval, modern liberal ideology. This ideology emerged from Bürgertum culture but more fully incorporated something of the radical undercurrent of the liberalist ethos to begin to effectively counteract the absolute command mentality of the medieval world. This counteracting would be slow, as reflected in the painfully slow process of democratization in England (later the United Kingdom).

England's emergent bourgeoisie would only gradually give up on feudal or aristocratic culture, and would long maintain aristocratic fear of the nation's vast propertyless class. Nevertheless, England did not collapse into absolute patrician-merchant oligarchy as the Dutch Republic did, and slowly but surely the spread of the liberalist ethos through English society undermined bourgeois conservatism and anti-democratic self-interest. With the rise of a Lockean-style liberalism, an ethos of individual empowerment began to trickle down the social strata. The bourgeois-aristocratic clique that ruled early-modern England, then, was undone by its own ideology, because even as this clique desperately tried to preserve its status the hegemonic culture it propounded demanded that the people take responsibility for their own lives and prove their worth through their aspiration. More and more classes of society combined their own self-interest with this culture of empowerment to demand equality of opportunity and to refuse their place in a static hierarchy. And when this populist energy combined with the force of the protestant radicals on the bourgeois fringe, the elite found time and time again that they would have to compromise with the people in order to maintain any legitimacy.[4] As Macpherson suggests (1962), even one of England's first modern popular movements for democratization - the Leveller movement of the English Civil War - was strongly marked by a bourgeois culture of self-emancipation. Macpherson uses his analysis to suggest that the Levellers were not working class activists at all, but petite bourgeois artisans who demanded rights only for themselves, not the masses, and who embraced the bourgeois desire for possession. Even if this were strictly true (and as Levy (1983) suggests, it is not at all clear that it is), it does not change the fact that these aspirant middling sorts were challenging bourgeois elitism by turning the elite's own self-emancipatory ethos against itself, and this was important because it helped to open up the productive process and prevent the collapse towards outright patrician oligarchy. Furthermore, by nurturing the culture that would prevent this collapse the Levellers became important precursors to later movements for popular empowerment, with northern England's working class Chartist movement of the 19th century following in the Leveller tradition.

In his famous study of liberalism's possessive individualism, Macpherson was right to point out that England's formative, popular democratizing movements were marked by self-interested groups clamoring for the right of inclusion in the individualist struggle for possession, but he was wrong to reduce such movements to this form of possession. Macpherson oversimplifies the Anglo-Saxon struggle for property by reducing it to the capitalist struggle to project self-possession onto the world - a projection that supports the notion that external objects, including people, can be claimed or owned by the self. For Macpherson the "possessive quality" of liberalism is found in the "conception of the individual as essentially the proprietor of his own person or capacities, owing nothing to society for them" (1962, 3, emphasis added). The problem with Macpherson's argument, as Levy (1983) points out, is that many early English radicals, including many at the heart of the Leveller movement, such as John Lilburne, were fundamentally opposed to the idea that the free individual owed nothing to society. Offering precursors to Lockean 
thought, Lilburne believed that the "Law of God" was "engraven in Nature," and that all men, regardless of status, had an essential moral worth or dignity derived from their sharing in God's Nature. Lilburne, like many Levellers, did defend the right to personal estate, but he did not make estate a prerequisite of equal rights - these rights were derived from the inherent worth in man's common spirituality. Like Locke after them, the Levellers defended a broad range of individual rights under the label "property." They reflected the contradiction of the liberalist ethos in that they turned to both individual trade and estate and egalitarian association to produce an effective counter-power to monarchical absolutism and elite bourgeois exclusivity. However much their complicity with bourgeois possession has complicated their democratic credentials, the communal, spiritual radicalism they nurtured as an essential feature of their worldview has been a vital cultural legacy for later left-wing radicals championing participation and cooperation over atomization and competition.

In this article we have reached the point where we find a radical liberalist ethos brewing in 17th century England but struggling to break free from aristocratic-bourgeois conservatism. A defining feature of this ethos is its refusal to be contained in a constituted order - as Hardt and Negri might say, it is deterritorializing by nature, seeking flight from its containment. Inevitably, then, radical bourgeois and petite bourgeois Puritans from England fled the country driven to self-constitute a new society. They fled to America to found New England - for them, a better England, one free from the corrupting influences holding England back. In doing so, as Hardt and Negri suggest, they laid the foundations for the modern Western world (here understanding 'modern' in a general sense, not an academic sense). Yet when the Anglo-Americans published the Declaration of Independence in 1776 - a document which, for Hardt and Negri, expressed a radical democratic ethos (see 2001, 165) - we should remember that it was a Declaration made in the name not of the multitude per se but of the property-owning classes of the 13 Colonies - the cultural (and in many cases, actual) descendants of the bourgeois, petite bourgeois and aspirant emigrants to America who dreamed of a land of unbounded opportunity for spiritual and material betterment. Since the American Revolution the AngloAmericans have spearheaded the global spread of a prolonged individualist revolution, which, in proclaiming the rights of the individual, has unleashed conflicting tendencies of democratization and competitive struggle. As Hardt and Negri suggest, the Anglo-American break was to a great extent driven forward by revolutionary, democratizing desire, and while this undermined the European elite's command mentality, the Americans still carried with them Europe's corrupting culture of power, which would break out in a new tradition of possessive control.

Following in the radical Anglo-Saxon tradition, when the Occupy movement emerged in the United States in 2011 - with the Americans inspired by their European cousins' struggles against debt and austerity - it was marked not so much by a reaction against American culture as it was by an embrace of the radical edge of America's liberalist ethos. Many Occupy protesters flew American flags - some flew upside down ones, hinting at their desire to turn America on its head by embracing its revolutionary undercurrent (See A Typical Faux, 2012). When the New York City General Assembly occupying Wall Street in Liberty Square issued its declaration on its purpose and demands, its writers echoed the sentiments of the Declaration of Independence and the Founding Fathers, stating that the people must cooperate to form government to protect their rights, and that upon corruption of the government, "it is up to... individuals to protect their own rights, and those of their neighbors” (New York City General Assembly, 2011). In their calls for the 99\% to embrace "direct democracy" and a new collective spirit, the occupy demonstrators founded their argument on a radical, anarchistic (and certainly not Tea Party-esque) version of American libertarianism; on the notion that individuals and local communities must themselves act to uphold their rights in equality, embracing participation and contribution to the common good. One American Occupy protester, complete with Guy Fawkes mask and a "we are the 99\%" jacket, held a sign that played on the famous Uncle Sam World War One recruitment poster. Complete with Uncle Sam finger pointing, the contemporary version of the poster declared "I want YOU to stop being AFRAID," with the poster listing various "others" Americans should stop being afraid of, including "other classes." It finishes by declaring "YOU'RE AMERICANS, ACT LIKE IT." The message seems pretty clear: be a true American - fight for your rights, but always in communion with your fellow human beings.

As Douzinas notes, the Occupy protesters, along with the aganaktismenoi and indignado occupiers in Europe, reacted against the dehumanizing accumulation logic of neoliberal globalization, which radicalizes the possessive and power-grasping tendencies of liberal individualism (see 2013, 25-30 and 91). Building on Foucault's concept of biopower, leftist scholars like Douzinas suggest that the neoliberal logic of accumulation has, since the 1980s, penetrated deep into the political fabric of liberal-democratic society. In the process, despite the fact that its advocates promote freedom from the state, the neoliberal logic underlies the emergence of an authoritarian state determined to discipline human bodies for consumption and preserve the free market at all costs. Here neo-liberalism pushes classical liberalism further by insisting that the state should not just protect the market in the last instance with 
a legal framework and a monopoly on force, but should act as an overarching (yet pervasive) power that steadfastly monitors free-market society and is ready to intervene with all its might whenever necessary to save the system. This is why even the Bush administration recognized that the banks and other financial companies could not be allowed to fail en masse during the Financial Crisis of 2007-08 - the elite had learnt this lesson from the Wall Street Crash of 1929 and the ensuing Great Depression (see The Washington Times, 2008). The loans and purchasing of debt and financial assets by the Federal Reserve and the Bush administration protected private interests en masse - the policies buttressed the position of the corporate elites and protected the savings and investments of ordinary members of the public. Under a neoliberal system in which the public literally buys into the free enterprise dream, the public's limited stake in the economy must be the government's concern. And it is argued that the public buy into this dream because the tentacles of the overarching power penetrate deep into society, generating business and management networks to induce individuals to embrace the free-market way. Neoliberalism, then, actually embraces a certain form of proactive governmentality, being driven forward by a market fundamentalism that is determined to inscribe the logic of competitive individualism into the very biology of social subjects.

From the perspective outlined above, then, neoliberalism is today's pervasive capitalist culture that compels individuals to view themselves as self-sufficient, isolated units whose sense of sociality is tenuously based on cold, calculative self-interest. Such individual "units" are consequently primed for austerity, ready to take on the necessary level of self-responsibility that will protect governments from the "burden" of welfare spending and protect society from the "affliction" of "dependency." This article has not sought to undermine this critically important perspective on the extent and threat of neoliberal power; it has sought only to add that neoliberalism represents only one (dominant) strand of liberal culture, and that the anarchistic direct democracy of the squares of 2011 helped give expression to a genuinely revolutionary associational/egalitarian individualist tradition, which has emerged in tandem with possessive individualism but which has on a fundamental level remained in contradiction with it. As neoliberal globalization, then, has speeded up the spread of its possessive biopower through the world system, it has inadvertently spread with itself an undercurrent of liberalist radicalism that it can never effectively absorb or pacify; this radicalism propagates a spiritual or deeply social sense of self-interest, advancing a communalist notion of enrichment that connects individual liberty with the common good. This article has connected this sociallyinclined notion of individual liberty with what Douzinas identifies as the social ethos of contemporary anti-capitalist resistance movements.

The argument presented here opposes the standard anti-postmodernist leftist argument on contemporary resistance, which, as alluded to at the beginning of the article, is perhaps best exemplified by Žižek. Žižek was critical of both the European and Occupy movements of 2011 because he thought they were too obsessed with enjoying themselves, prioritizing spontaneity and playfulness in the squares over group discipline and pro-active decision making (2011 and 2012). For Žižek the demonstrators did not offer a viable alternative to capitalism but lived through capitalist non-ideology by indulging themselves in rebellion, refusing to develop a revolutionary project. I argue here that what Žižek has failed to grasp is that the spirit of revolt of the contemporary age - which prioritizes the cultivation of democratic participation and inclusion over forced decisions and the general will - marks the development and/or the becoming of an alternative revolutionary tradition, which is centuries in the making and which has outflanked the type of socialism he clings to. The indignados and Occupiers may have drawn on liberalist notions of individual freedom and autonomy to develop their joyous and undirected movements, but this is as much to their strength as to their weakness, for the egalitarian individualist notions of community and sociality that they nurture cannot be reduced to neoliberalism's instrumentalist sociality.

The challenge is to continue to nurture these progressive notions of community and sociality in the face of neoliberal biopower and the temptations to turn individual empowerment into individual power-seeking. In order to continue to nurture a progressive culture of egalitarianism, this article has suggested that it is necessary to inhabit, work through and draw out the genuinely radical energies inherent in the liberalist cultural context, undermining the pervasive and corrupting neoliberal concept of individual freedom in the process. Nevertheless, as suggested at the beginning of this article, this is not an easy task, for contemporary resistance movements are to a large extent dependent on the dynamics of the neoliberal system, and may well be compelled to intensify their struggle to revolutionize society by the relentless active agency and imperatives of speed produced by the system. Members of such movements, then, caught in liberalism's humanist aporia, always carry the potential to assert their power or right to possession through such movements, even as they struggle to overcome selfishness and reinvent themselves in common with others. However, this article has sought to follow Hoofd's (and incidentally, Hardt and Negri's) lead by insisting that it is better to work through the radical dynamics that exist within the current cultural system 
than to dream of a pure anti-capitalist utopia beyond the touch of liberal capitalism. The point here is not to resign ourselves to the impossibility of moving beyond the current state of affairs, but to figure out how best to draw out the associational-egalitarian dynamics from the possessive neoliberal context from which they emerge, helping an already existing radical democratic spirit to continue to grow.

\section{Notes on Citations of Works by Spinoza}

- TTP refers to the Tractatus Theologico-Politicus, or Theological-Political Treatise. Citations refer to chapter, then page number (e.g., 6, 18 refers to chapter 6 , page 18 ).

- TP refers to the Tractatus Politicus, or Political Treatise. Citations refer to the chapters/sections (e.g., $2 / 6$ refers to chapter 2 , section 6 ).
- E refers to the Ethics. Citations use the following abbreviations: Roman numerals refer to parts; "P" followed by number refers to proposition; "C" refers to corollary; " $D$ " refers to definition, "S" refers to scholium (e.g., EIVP18S refers to Ethics, part 4 (IV), proposition 18, scholium).

\section{Endnotes}

1. For Žižek, Spinoza lays the foundations of modern thought by proposing a radical ontology of one Substance, out of which emerges a multitude of contradictory affects that cannot be reduced to either positive or negative outcomes. Žižek argues, however, that Spinoza remains limited by his belief that out of the one Substance emerges entities that have only a positive striving to persevere in their being. For Žižek, Spinoza shies away from the negativity of being - the death drive of beings, and Deleuze follows in Spinoza's path with his vitalism; 'his elevation of the notion of Life to a new name for Becoming as the only true encompassing Whole, the One-ness, of Being itself' (2004, Deleuze, section 5).

2. Indeed, Feuer suggests a direct connection between the philosophy of Spinoza and Locke (1958, "Epilogue"), noting that Locke travelled to Holland in 1684 and came under the influence of a group of Spinozists. During this period in Holland, Locke wrote the Letter Concerning Toleration.
3. George Berkeley seemed to recognise what was at stake when he suggested in his Treatise Concerning the Principles of Human Knowledge (2007 [1710]) that Locke's rejection of innate ideas would inevitably lead to atheism. Berkeley recognised, then, that Locke's own deep religiousness was being undermined by his empiricism.

4. Following a similar historical trajectory to this thesis, Arrighi et al. (2003) track the spread of capitalism (as a fundamental feature of government) from the Italian city-states to the Dutch proto-nation-state and on into a centralised state - England. They discuss the argument that capitalistic practices became more deeply entrenched in national cultures as capitalism was embraced by increasingly complex states. What this article focuses on is the spread of the liberalist or individualist ethos that developed in tandem with this intensification of capitalist government. The liberalist ethos underpins capitalism and shapes the direction of its evolution. 


\section{References}

Armitage, D. (2004), “John Locke, Carolina and the "Two Treatises of Government," Political Theory, Vol. 32, No. 5 (Oct., 2004), pp. 602-627.

Arrighi, G., Hui, P., Hung, H. and Selden, M. (2003), "Historical Capitalism, East and West.” The Resurgence of East Asia: 500, 150 and 50 Year Perspectives . Eds. G. Arrighi, T. Hamashita, and M. Selden. London: RoutledgeCurzon, pp.259-316.

Barbone, S. (2001), "What Counts as an Individual for Spinoza?" In Spinoza: Metaphysical Themes, Eds. O. I. Koistinen and J. I. Biro. New York: Oxford University Press, pp.89-112.

Berkeley, G. (2007 [1710]), The Principles of Human Knowledge . Ed. J. Bennett, Retrieved from webpage: http://www.earlymoderntexts.com/pdfs/berkeley1710.pdf, accessed 04/05/2014.

DeKoven, M. (2004), The Sixties and the Emergence of the Postmodern. London: Duke University Press.

Deleuze, G. and Guattari, F. (1984), Anti-Oedipus: Capitalism and Schizophrenia . Trans. R. Hurley, M. Seem, and H. R. Lane. London: The Athlone Press.

Deleuze, G. and Guattari, F. (1988), A Thousand Plateaus: Capitalism and Schizophrenia . Trans. B. Massumi. London: The Athlone Press.

Den Uyl, D. J. (1983), Power, State, and Freedom; an Interpretation of Spinoza's Political Philosophy . Assen, The Netherlands: Van Gorcum \& Company.

Dosse, F. (2010), Gilles Deleuze and Felix Guattari: Intersecting Lives . Trans. D. Glassman. New York: Columbia University Press.

Douzinas, C. (2013), Philosophy and Resistance in the Crisis . Cambridge: Polity Press.

Dutton, B. D., "Benedict de Spinoza." Internet Encyclopedia of Philosophy. Webpage: http://www.iep.utm.edu/spinoza/, accessed 01/04/2014.

Field, S. (2012), "Democracy and the Multitude: Spinoza against Negri." Theoria, June 2012, pp. 21-40.

Feuer, L. S. (1958), Spinoza and the Rise of Liberalism . Boston: Beacon Press.

Friend, C., 'Social Contract Theory'. Internet Encyclopedia of Philosophy . Webpage: http://www.iep.utm.edu/soc-cont/, accessed 12/07/2013.

Hardt. M. (2006 [1983]), "Foreword," in G. Deleuze, Nietzsche and philosophy. Trans. H. Tomlinson. Columbia University Press.

Hardt, M. and Negri, A. (2001), Empire. Harvard University Press.
Hoofd, I. M. (2012), Ambiguities of Activism: Alter-Globalism and the Imperatives of Speed. London: Routledge.

Israel, J. I. (1995), The Dutch Republic: Its Rise, Greatness, and Fall, 1477-1806. Oxford: Clarendon-Press.

Levy, M. B. (1983), "Freedom, Property and the Levellers: The Case of John Lilburne." The Western Political Quarterly, Vol. 36, No. 1 (Mar., 1983), pp. 116-133.

Locke, J. [1689], Two Treatises of Government. From The Works of John Locke (A New Edition, Corrected), 1823, Vol. V. Prepared by Rod Hay for the McMaster University Archive of the History of Economic Thought, available at http:// socserv2.socsci.mcmaster.ca/econ/ugcm/3113/locke/government.pdf, accessed 02/02/2013.

Locke, J. (1958 [1695]), The Reasonableness of Christianity, as Delivered in the Scriptures. With A Discourse of Miracles and part of A Third Letter Concerning Toleration. Ed. I.T. Ramsey. Stanford: Stanford University Press.

Macpherson, C.B. (1962), The Political Theory of Possessive Individualism. Oxford University Press.

New York City General Assembly (2011), "Declaration of the Occupation of New York City." Retrieved from The Sparrow Project, webpage: http://www.sparrowmedia.net/declaration/ , accessed 06/06/2012.

Niemi, J. (2013), "Benedict de Spinoza: Political Philosophy." Internet Encyclopedia of Philosophy. Webpage: http://www. iep.utm.edu/spin-pol/, accessed 23/07/2013.

Nyden-Bullock, T. (2007), Spinoza’s Radical Cartesian Mind . London: Continuum.

Petry, M. (1984), "Hobbes and the Early Dutch Spinozists.” Spinoza's Political and Theological Thought. Ed. C. De Deugd. Amsterdam: North-Holland Publishing, pp. 63-72.

Robin, C. (2011), The Reactionary Mind: Conservatism from Edmund Burke to Sarah Palin . Oxford: Oxford University Press.

Sharp, H. (2013), "Spinoza and the Revolutionary Laws of Human Nature.” Eds. E. R

Jimenez, M. Lampert, C. Roberts, and R. Zambrana. Graduate Faculty Philosophy Journal , 34 (1), pp.133-148.

Spinoza, B. de (1985). The Collected Works of Spinoza, Vol. I . Ed. and trans. E.M. Curley. Princeton, N.J.: Princeton University Press.

Spinoza, B. de. (2000), Political Treatise. Trans. S. Shirley. Indianapolis: Hackett. 
Spinoza, B. de. (2007) Theological-Political Treatise . Ed. J. Israel, trans. M. Silverthorne, and J. Israel. Cambridge: Cambridge University Press.

Steinberg, J. (2013), “Spinoza's Political Philosophy.” The Stanford Encyclopedia of Philosophy. Winter 2013 Edition, Ed. Edward N. Zalta, webpage: http://plato.stanford.edu/archives/ win2013/entries/spinoza-political/, accessed 07/02/2013.

Tuckness, A. (2012), "Locke's Political Philosophy." The Stanford Encyclopedia of Philosophy. Winter 2012 Edition, Ed. Edward N. Zalta, webpage: http://plato.stanford.edu/archives/ win2012/entries/locke-political/ , accessed 23/03/2013.

A Typical Faux, (2012), "Occupy - Still Free (Take a Chance on Me) [Full]," You Tube, 17/03/2012, https://www.youtube. com/watch?v=HIYMLR_DGWU, accessed 08/06/2012.

Uzgalis, W. (2012), “John Locke.” The Stanford Encyclopedia of Philosophy . Fall 2012 Edition, Ed. Edward N. Zalta, webpage: http://plato.stanford.edu/archives/fall2012/entries/locke/, accessed 14/06/2013.
The Washington Times, (2008), “Panic Control.” Webpage:

http://www.washingtontimes.com/news/2008/may/12/panic-control/, accessed 09/08/13.

Žižek, S. (2004). Organs without Bodies. London: Routledge.

Žižek, S. (2011), "Shoplifters of the World Unite." London Review of Books, 19 August 2011. Webpage: http://www. lrb.co.uk/2011/08/19/slavoj-zizek/shoplifters-of-the-worldunite, accessed 25/08/2011.

Žižek, S. (2012), "Occupy Wall Street: What is to be Done Next?” The Guardian, 24 April 2012. Webpage: http:// www.theguardian.com/commentisfree/cifamerica/2012/ apr/24/occupy-wall-street-what-is-to-be-done-next, accessed $30 / 04 / 2014$. 
